\title{
ROLE OF REDUCING CELL LEAKAGE IN CELL CULTURE USING LARGE PORE SIZE PERMEABLE MEMBRANE
}

\author{
Nur Kaliwantoro \\ Mechanical Engineering Department \\ Engineering Faculty- Mataram University \\ Email: kaliwantoro@gmail.com \\ Marsetyawan HNE Soesatyo \\ Histology and Cells Biology Department-Medical Faculty \\ Universitas Gadjah Mada \\ Indarto \\ Mechanical Engineering Department, Engineering Faculty \\ Universitas Gadjah Mada \\ Mohammad Juffrie \\ Pediatric Department, Medical Faculty \\ Universitas Gadjah Mada \\ Rini Dharmastiti \\ Industrial Engineering Department, Engineering Faculty \\ Universitas Gadjah Mada \\ Suprihatin \\ Parasitology Laboratory, Medical Faculty \\ Universitas Gadjah Mada
}

\begin{abstract}
ABSTRAK
Membran permeable banyak dipergunakan dalam penelitian in vitro kultur sel. Kebocoran sel sangat sering terjadi ketika membran permeabel yang dipergunakan memiliki ukuran pori-pori yang relatif besar. Di sisi lain, pemakaian membran permeable dengan pori-pori yang lebih kecil pada studi permabilitas banyak menghadapi kesulitan teknis akibat kecilnya ukuran pori dan densitas pori-pori membran. Penelitian ini menghadirkan teknik memperkecil kebocoran sel pada kultur sel yang mempergunakan membran permabel berpori-pori besar. Vero cell line (CCL-81, ATCC) dipergunakan sebagai sel objek dan dikultur pada membran polyester yang memiliki ukuran pori $3 \mu \mathrm{m}$. Visualisasi dengan bantuan mikroskop dipergunakan untuk menganalisa kebocoran sel. Adapun untuk menguji kinerja permeabilitas sel dipergunakan parallel plate flow chamber. Hasil penelitian mendapatkan bahwa temuan teknik yang dipakai mampu menurunkan kebocoran sel secara signifikan pada kultur sel dengan membran permeabel berpori-pori besar. Hasil yang sama juga dijumpai pada pemakaian membran permeabel yang terbuat dari polyester dan polycarbonat.
\end{abstract}

Kata Kunci: Kebocoran sel; Membran permeabel; Parallel plate flow chamber; Sel vero; Ukuran pori.

\section{ABSTRACT}

Permeable membranes are widely used in many in vitro studies using cell culture. Some cell leakage are often occurs when using permeable membrane with large pore size. Unfortunately the use of permeable membrane with smaller pore 
size in permeability studies faces some difficulties due to its small pore size and pore density. Recent study provides the protocol in using permeable membrane with large pore size with smaller cell leakage. Vero cell line (CCL81, ATCC) was used and culture on polyester permeable membrane with $3 \mu \mathrm{m}$ pore size. Visualization using inverted microscope was used to analized the cell leakage on the permeable membrane. Parallel plate flow chamber was used to analized the permeability performance of the Vero cell cultured on the permeable membrane. The result showed that the current technique is significant in reducing cell leakage of the cell cultured on large pore size of permeable membrane. The same results were found in using polyester and polycarbonate permeable membrane.

Keywords: Cell leakage; Parallel plate flow chamber; Permeable membrane; Pore size; Vero cells.

\section{INTRODUCTION}

The use of permeable membrane as cells attachment are widely used in the study of drug transport, chemotaxis, cell-cell communication and pathology of several diseases with the change of permeability like dengue infection, Rickettsia and inflammation (Corning, 2010).

One type of permeable membrane availabled commercially is the polyester permeable membrane. This type of permeable membrane has better visibility under phase contrast microscope compared to polycarbonate membrane. General recommended poresize for the permeability studies are $0.4,1$ and $3 \mu \mathrm{m}$ (Corning,2010). But the use of $0.4 \mu \mathrm{m}$ poresize of polyester for studies the permeability is very hard due to its small pore size and number of pore density $\left(4.10^{6}\right)$, compared to polycarbonate with the same pore size that has $1.10^{8}$ pore density. In another hand, the use of Polyester transwell permeable membrane with $3 \mu \mathrm{m}$ pore size causes a lot of cell leakage. Unlike the PC membrane, the Polyester membrane with pore size of $1 \mu \mathrm{m}$ are not available commercially.

Previous studies of permeability commonly used the Polycarbonate membrane with $0.4 \mu \mathrm{m}$ (Casnocha, 1990; Wahyudi, 2006), but the use of Polycarbonate membrane gives difficulties in monitoring the cell growth on the membrane due to its invisibility. Cell leakage using $3 \mu \mathrm{m}$ pore size were also reported in the studies using Polycarbonate membrane (Casnocha, 1990).

In the permeability study, the governing principle for one dimensional mass transport of species A in species B is Fick's first law of diffusion:

$$
J_{A x}=-D_{A B} \frac{d C_{A}}{d x}
$$

Where $\mathrm{J}_{\mathrm{Ax}}=$ mass flux of $\mathrm{A}$ in the $\mathrm{x}$-direction; $\mathrm{D}_{\mathrm{AB}}=$ diffusion coefficient of $\mathrm{A}$ in $\mathrm{B} ; \mathrm{dC}_{\mathrm{A}} /$ $\mathrm{dx}=$ concentration gradient of $\mathrm{A}$

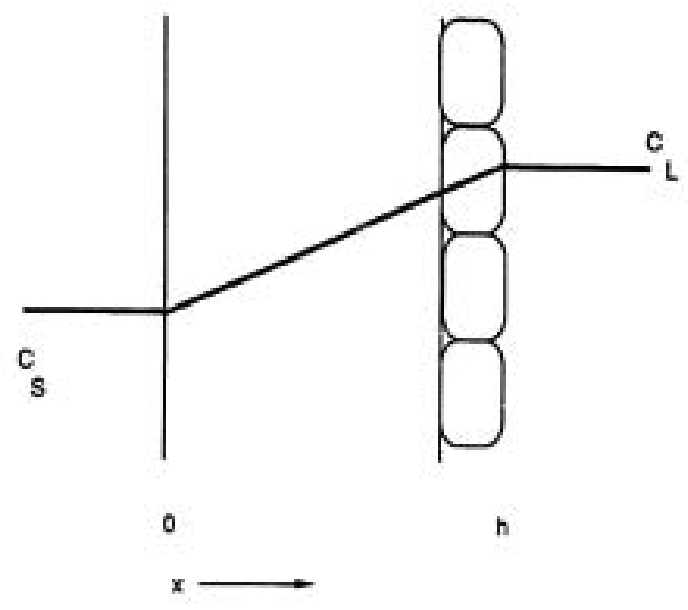

Figure 1.

A cross section of the membrane-monolayer composite showing the system geometry and concentration profile (Casnocha, 1990)

In case of transwell having luminal and sublimal section, the permeability is defined as:

$$
\begin{aligned}
& P C=\frac{J_{A X}}{C_{L}-C_{S}} \\
& J_{A X}=\rho_{A}\left(V_{A 1}-V_{A 2}\right)
\end{aligned}
$$

Where $\mathrm{PC}=$ permeability coefficient, $\mathrm{J}_{\mathrm{AX}}=$ Mass flux across permeable membrane, $\mathrm{C}_{\mathrm{L}}=$ concentration of luminal section, $\mathrm{C}_{s}=$ concentration of subluminal section, $\rho=$ density of species $\mathrm{A}, \mathrm{V}=$ volume of species $\mathrm{A}$.

In the cell culture using large pore size, the permeability can also be analized using the mass flux across directly through the membrane for a determined time. 
Based on previous problems, recent study gives the protocol in using permeable membrane with $3 \mu \mathrm{m}$ pore size with small number of cell leakage as well as the performance of permeability using large poresize permeable membrane.

\section{Material and Method}

Vero cell line (CCL-81, ATCC) were provided at the Parasitology Laboratory, Medical Faculty of Gadjah Mada University, Indonesia. $24 \mathrm{~mm}$ transwell polyester permeable membrane with $3 \mu \mathrm{m}$ were supplied by Corning (cat. 3452). Culture media M199 and FBS were supplied by Gibco. $10 \mathrm{~cm}$ petridishes were supplied by Iwaki. Parallel plate flow chamber used in permeability test was manufactured based on previous research.

\section{Reducing Cell Leakage in Culturing using Large Pore Size Permeable Membrane}

Vero cell line was harvested, centrifuged and put the pellet into a falcon tube. Added some complete media contains M199 and FBS until the cell density reach 1.000 .000 cells/ $\mathrm{ml}$. Four $24 \mathrm{~mm}$ transwell polyester transwell (PET) permeable membrane with $3 \mu \mathrm{m}$ were carefully put on two $10 \mathrm{~cm}$ petridishes (each petridish contains 2 transwell PET). Carefully pipetting $250 \mu \mathrm{l}$ of media contains vero cell into each PET permeable membrane. Added $750 \mu 1$ of complete M199 media into each PET transwell permeable membrane. Put the lid of the petridish in such away that the lid of the petri press the bottom of the permeable membrane on the base of the petridish. The petridish was sent into the $\mathrm{CO}_{2}$ incubator for 48 hours. After that, a 6 well plate was prepared by pouring $500 \mu 1$ of M199 media into each well. The old media in each transwell that put in the petridish for $48 \mathrm{~h}$ in the $\mathrm{CO}_{2}$ incubator was removed. Each transwell was then put into the 6 well plate. After that, $1000 \mu$ of M199 media was put into each PET transwell. The 6 well plate that contains PET membrane was then sent back into the $\mathrm{CO}_{2}$ incubator. The complete media was replaced each 3 days until the cell reach its monolayer.

\section{Cell Leakage Test}

Cell leakage was analysed by visualization using inverted microscope on the petridish surface below the transwell permeable membrane. The bottom surface of the transwell was also analysed using inverted microscope, and compared to original condition of the transwell that has not used in the culture.

\section{Permeability Test}

The method of transwell experiment adopted in the recent work was a modification from the method reported by Yen et al (2008) and Casnocha (1990).

Vero cells were grown to confluent monolayer in the upper chamber of polycarbonate membrane transwell by seeding at $2 \times 10^{6}$ cells/ $\mathrm{cm}^{2}$ and incubated for 72 hours. Trypan bluelabeled bovine serum albumin was prepared by adding $180 \mathrm{mg}$ trypan blue (Sigma) and 4 $\mathrm{g}$ bovine serum albumin fraction V (Sigma) to $100 \mathrm{ml}$ Hanks balanced solution (Gibco) and precipitated with $5 \%$ tricholoroacetic acid. Trypan blue-stained bovine serum albumin was flowed to the upper chamber of the transwell. After the medium flow for 30 minutes, the fluid in the lower chamber was picked for $2 \times 10 \mu$ l. Then, the fluid was stirred to homogenized the albumin and the serum. $2 \mu \mathrm{l}$ of this homogenized albumin-serum was analysed using microscope to determine the amount of albumin across the vero cells. The transwell membrane with vero cells were then removed to be visualized using inverted microscope.

\section{RESULT AND DISCUSSION Reducing Cell Leakage in Culturing using Large Pore Size Permeable Membrane}

In the recent work, after two days the transwell permeable membrane was put on the $10 \mathrm{~cm}$ petridish, only a little amount of media leaked and wet around the outer side of transwell (Figure 2). The leakage volume was highly affected by some factors: (1) the tightness of the petri lid, (2) the frequency of inspection of cell culture, that usually followed by any shakings of the petri dish. It was recommended that the frequency of cell culture inspection 
no more than twice when the transwell was placed in the petri dish. On the third day, the cell was assumed to have been grown stable, attached tightly on the permeable membrane, and then the transwell were removed to 6 well plate as shown in Figure 3.

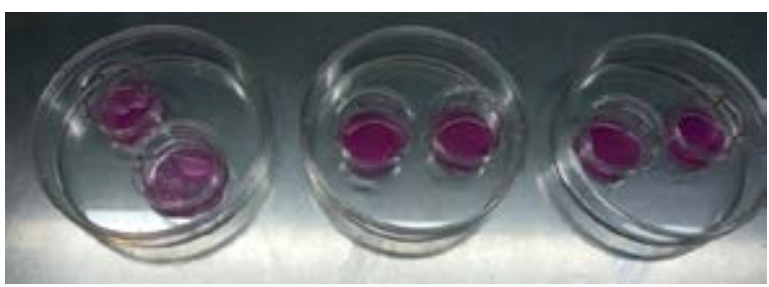

Figure 2.

Vero cells cultured on the transwell permeable membrane were put on to petridish and closed tightly using their lids to reduced cells leakage across the membrane

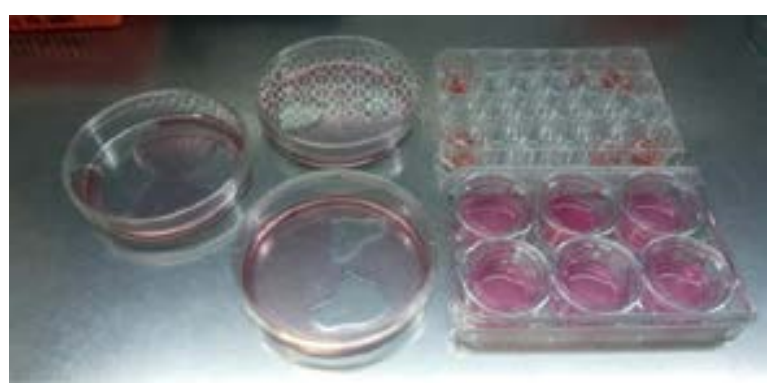

Figure 3.

At the third day, the transwell were moved into 6 wells plate. Fluid in the petridish was the media leakage from thecell culture when the transwell was placed in the petridish for 48 hours. Fluid in the 24 wells plate came from the remained fluid in the luminal section of the transwell permeable membrane.

One of the big difficulties in the culturing cell on the permeable membrane was the determination whether the cell culture have reached confluency without destroy the cells. It appeared since the shape of the cell before seeding almost the same with the shape of membrane pores. Recent study used microscope to visualize the cell growth on the membrane. As shown in Figure 4,a, the membrane pores have perfectly circular shape, while the cells' shape were not perfectly circular and slight larger than the pores (Figure. 4,b). By the time the cells grew up and the shape became larger and covered the permeable membrane as well as its pores (Fig. 4.c and Fig. 4.d).

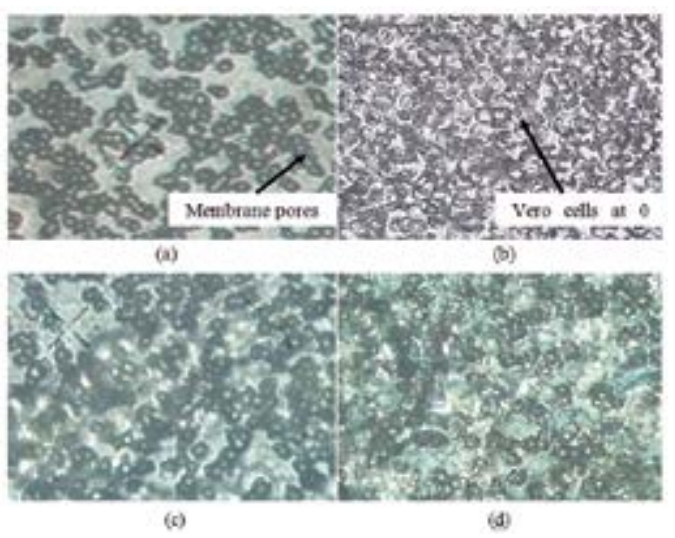

Figure 4.

Permeable membrane without cells (a), Vero cell seeding on the permeable membrane at 0 hour (b); vero cell culture after 24 hours (c) and 48 hours post seeding $(\mathrm{d})$

The modified procedure has been proven to be effective in preventing the cell migration across the relatively large size permeable membrane as shown by Figure 5 (a) - (c). At those figure it is seen that the media at the subluminal section almost free of cells, which indicated only a little amount of cells could migrate across the permeable membrane. Such condition could be achieved since the transwell was pressed tightly enough on to the surface of the petri dish using its lid.

A more proof of the effectiveness of the modified technique in preventing cell leakage were also shown in Figures 6 (a) - (d). The transwell surface wetted by media containing no cells (Figure 6.b) was almost as smooth as the surface of pre-treated transwell (Figure 6a). In contrast, the surface of the transwell that has been cultured by vero cells was seems a rough one (Figure 6.c), while the outer surface of the bottom side membrane (Figure 6.d) was smoother than the inner side membrane of the transwell. 


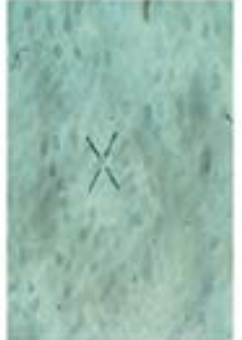

(a)

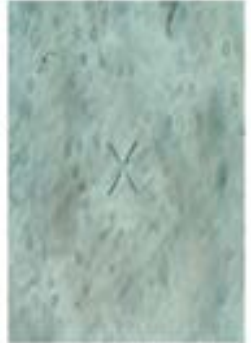

(b)

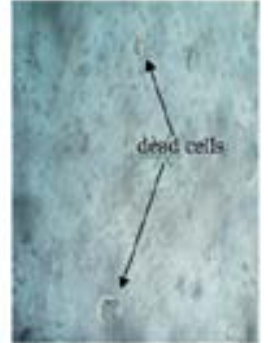

(c)
Figure 5.

The views below the microsope without any object (a); media at the subluminal section of the transwell (b); media at luminal section (c)
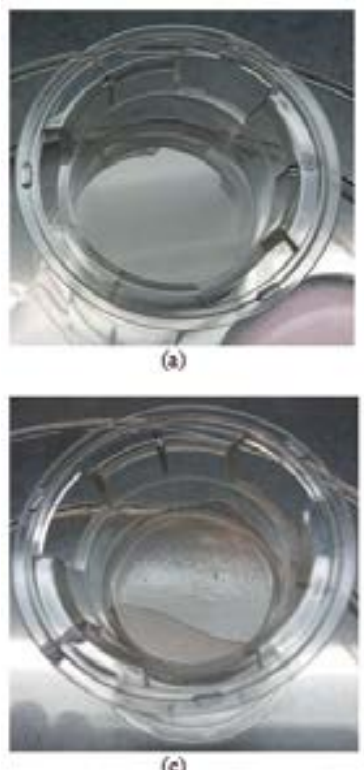

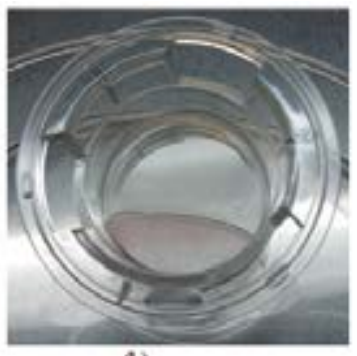

(b)

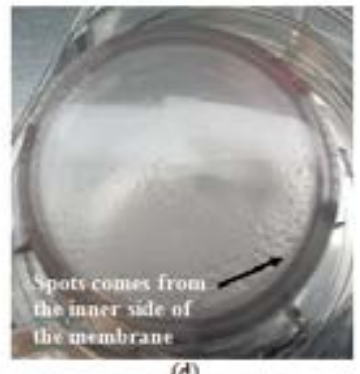

(d)
Figure 6.

The view of the surface of pre-treated transwell (a); the surface of the transwell wetted by media containing no cells (b); the surface of the transwell that has been cultured by vero cells (c), the surface of the bottom side membrane (d)

\section{Permeability}

In this study, the performance of permeability under dynamic condition was analysed using parallel plate flow chamber made from acrylic material. The system built the this work is not employed any roller nor syringe pump as used by previuous research (Casnocha, 1990, Arslan, 2010), but fully uses the gravitation for flowing the culture media in the lining. The fluid capacity enters the system is controlled using a regulator in the pediatric infusion set. Since the diameter in the line of pediatric infusion is small, and the viscosity of the culture media analysed in this works has values up to $1,33 \mathrm{~mm}^{2} / \mathrm{s}$, then the media sink must be lowered first in each operation to trigger the fluid flowing in the whole line of the system.

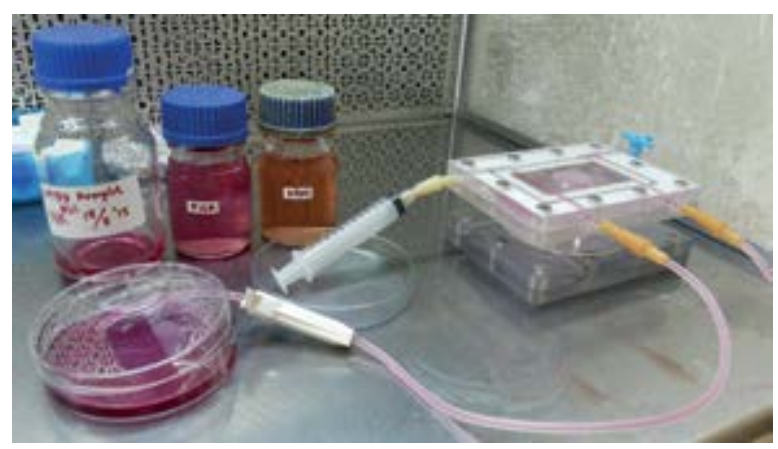

Figure 7.

Parallel plate flow chamber built in the recent study used permeable membrane for growing cells, also used pediatric infusion set to get a small fluid capacity as low as $1 \mathrm{ml} /$ minute

In the performace test of the permeability using parallel plate flow chamber, it was found that the permeability of the membranes that had been pre-treated in the petridish, $20 \%$ lower than those without any prea-treated in the petridish. It is indicated that the cell culture in the membrane with pre-treated more confluent and less cell leakage than the membrane without any pre-treated.

\section{CONCLUSION}

Cell leakage in the cell culture using large pore size permeable membrane can be reduced using the procedure explained in this study. The permeability of the permeable membrane under dynamic condition can be analysed using parallel plate flow chamber

\section{REFERENCES}

Arslan N, Isik S, Uykan O, 2010, “Steady and disturbed flow effects on human umbilical vein endothelial cells (HUVECs) in vascular system: an experimental study", Acta of 
NUR KALIWANTORO, MARSETYAWAN HNE SOESATYO, INDARTO, MOHAMMAD JUFFRIE, RINI, DHARMASTITI, DAN SUPRIHATIN $\&$ ROLE OF REDUCING CELL LEAKAGE IN CELL CULTURE ...

Bioengineering and Biomechanics, 12 (4): 3-9.

Casnocha, 1990, "Permeability of endothelial monolayers under stationary and flow condition", Dissertation, Michigan University, USA.

Corning, 2010, Corning Cell Culture Selection Guide.

Wahyudi, 2006, "Pengaruh Shear Stress terhadap sintesa dan release Nox dari HUVEC yang dipapar dengan Glukosa Suprafisiologis",Disertasi, Universitas Brawijaya.

Yen YT, Chen HC, Lin YD, Shieh CC, WuHsieh BA, 2008, "Enhancement by tumor necrosis factor alpha of dengue virus-induced endothelial cell production of reactive nitrogen and oxygen species is key to hemorrhage development", Journal of virology. 82:12312-12324. 